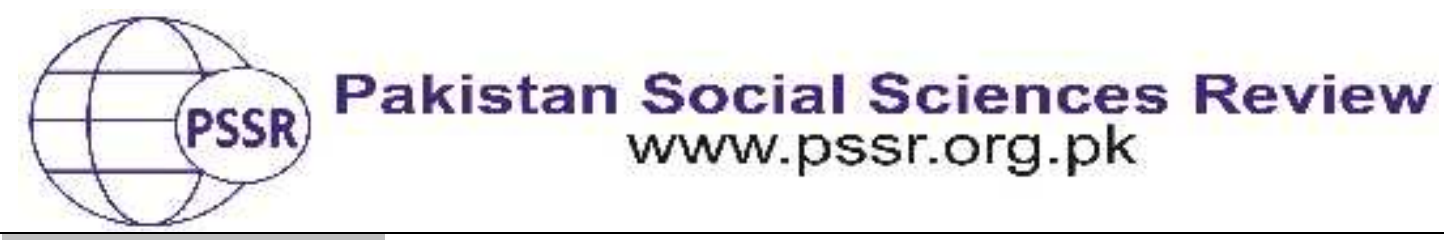

RESEARCH PAPER

\title{
Problems of Bonded Child Labor in Brick Kilns Industry at Peshawar, Pakistan
}

\author{
Muhammad Iqbal Shah ${ }^{1}$ Dr. Anwar Alam ${ }^{2}$ Dr. Muhammad Shabbir ${ }^{3}$
}

1. Ph. D Sociology, Department of Sociology, University of Peshawar, KP, Pakistan

2. Professor, Department of Sociology, University of Peshawar, KP, Pakistan

3. Assistant Professor, Department of Sociology, GC University Faisalabad, Punjab, Pakistan

\begin{tabular}{|c|c|}
\hline PAI & 1 \\
\hline $\begin{array}{l}\text { Rec } \\
\text { June } \\
\text { Acc } \\
\text { Augr } \\
\text { Onl } \\
\text { Septe }\end{array}$ & $\begin{array}{l}\text { This study was designed to probe into the exploitativ } \\
\text { of bonded child labor working with their parents } \\
\text { family members in the brick kiln industries. In tl } \\
\text { social conditions, exploitative means used again } \\
\text { labor, the extent and hazardous effects of bonded }\end{array}$ \\
\hline $\begin{array}{l}\text { Keywords: } \\
\text { Advance Money, } \\
\text { Bonded Labor, } \\
\text { Brick Kilns, } \\
\text { Loan Burden and } \\
\text { Child Labors } \\
\end{array}$ & $\begin{array}{l}\text { SPSS was applied for analysis. Sample size for the research was } \\
300 \text { children working at brick kilns with interview schedule } \\
\text { through simple random sampling. Primary data was analyzed } \\
\text { through SPSS using Statistical Chi-square for testing the } \\
\text { hypothesis. A non-significant association was found between }\end{array}$ \\
\hline Cor & \\
\hline 8 & $\begin{array}{l}\text { bonded child labor. A significant association was found } \\
\text { ween loan burden and bonded child labor. The researcher } \\
\text { ommends that government should provide free compulsory } \\
\text { mary education and make sure the implementation, increase } \\
\text { ome generating activities and schemes, and bonded labor } \\
\text { blition Act } 1992 \text { should be implemented strictly }\end{array}$ \\
\hline
\end{tabular}

\section{Introduction}

For every nation children are their prospective assets, they grow like flowers; blossom with novel day and raise with many effects they learn. Nearly all of us anxiously wait for the first expression they utter; they need opportunities and amenities for maturity as a good citizen. Children, mostly from poor and deprived class-backgrounds, work in the unfair labor throughout developing countries including Pakistan. Child labor is an evil and critical problem in today's world. Child labor in all underdeveloped and less technological develop countries including Pakistan is in its most horrible and manipulative form. Children are not only oppressed socially they also undergo morally and their personalities breed poorly in Pakistan. According to a World Bank survey, Pakistan lines the sixth most 
populous country in the world with 173.8 million people; Literacy rate in 2008 stood at 53 percent whereas infant mortality pace was noted to be maximum among South Asian countries. The right to education, the chances to play, and opportunities for standard physical advancement are basic human privileges which are denied to millions of children in Pakistan. It is intolerable that this circumstance exists even in the 21st century (Afzal, 2006).

Chaudhry and Garner (2007) study revealed that "Exploitative child labor is one of the burning and critical problems of Pakistan nowadays. Khyber Pakhtunkhwa is a hub of bricks kilns, where hundreds of child laborers are employed with their parents. In Pakistan, earning of one person is spent on the feeding of approximately 8 persons in an average family; and with the high pace of inflation, it becomes difficult for low-income families to survive. Child labor is increasing throughout Pakistan, but due to certain social factors, it is in the high emerging scale in the Khyber Pakhtunkhwa and its FATA (Federally Administer Tribal Areas) and PATA (Provincially Administered Tribal Areas)".

Among the early efforts, "the United State of America (USA) has made legislation and was passed in respect of elimination of child labor. In this connection, the popular one is, "The Child labor Deterrent Act in 1992". This bill is widely known as a Harkin Bill (ILO, 2004).

\section{Child Labor}

ILO (2004) defines "Child labor as the labor where such work deprives children of their schooling, entertainment, childhood, their potential, dignity and that is hazardous to their mental and physical development".

\section{Bonded Labor}

According to the Report of National Coalition Against Bonded Labor, "The State of Bonded Labor in Pakistan, "Bonded labor refers to the work, which is performed by any member of the debt bondage family for their Master / Owner on nominal wages on weekly payment; until the loan is repaid; In the contract period of "Peshgi" (advance payment) the debt-bonded family cannot seek employment or any income generation source and move freely outside." (Rogaly, 2008).

\section{Forced labor:}

In a press release in Lahore on June 25, 2012, Human Rights Commission of Pakistan (HRCP) referred that bonded labor remains one of the sensitive issue of the country. It is spread in the country in several forms and law is exploited even after 20 years of its establishment. The state and civil society should multiply their efforts to get rid of this wickedness. The statement in the press was released after consulting with the stakeholders who participated in a workshop organized by the HRCP (HRCP, 2012). 


\section{Bricks Production Trend in Pakistan}

Iqbal (2006) described that brick production is not a new phenomena in Pakistan especially in subcontinent. It had a long history not even in subcontinent but also in all over the world. Especially, if we read about Indus valley civilization (2500-1500 BC), brink production was the part of culture and those people used bricks production in the construction of buildings. While the earliest population in Mesopotamia and Egypt had constructed large monument and their residential buildings with bricks.

In this brick business, "Peshgi" is an amount that is offered as an advance to laborers before starting work with owners. Peshgi becomes a tradition for laborers and owners both and it is considered as verbal debt bondage. After this bondage, laborer is bond to work on that brick kilns. Mostly, this verbal contract is on seasonal calendar. Laborers received "peshgi" through an important middle laborer (influential person) called "Jamadar" who is responsible for organizing the working force for the owner. In KPK called "Jamadar" and in Punjab "Labor Mate"). In Punjab he is also called labor Mate, who is a responsible for entering into an agreement (verbal) of "peshgi" between Owner and laborers. Such practice has several obligations on the working class and on the owners as well. Though the more disadvantaged and vulnerable status is of the workers class and the owners are exploiting the energies of his laborers. Every member of the bondage family is trying to reduce the burden of debt but unfortunately due to certain social and cultural circumstances the laborers are highly suffering. The burden of debt is continual and it is difficult for people to get rid of this debt. It is a common practice that the owner engaged the generations and families including female members and children as well (Afzal, 2006).

\section{Facts and Figures of Bonded Brick Kilns Labor in Pakistan}

Pakistan Institute of Labor Education and Research (PILER) are working on labor issues in Pakistan. The institute reported that around 90 percent of brick kilns were operating in the rural area of the country where a number of families were engaged in bonded labor. This labor was cheap and the owners took full advantage of available cheap labor force as well as their families by engaging them in work. According to the PILER, up to 5000 bricks kilns were working in Punjab Province while around 6000 were working in all other Provinces including Sindh, Balochistan, KPK and others (Ali \& Hamid, 1999).

Bonded child labor has outlawed and already been banned in Pakistan as after the convention of United Nations in which human rights were discussed. However, practically situation is different in Pakistan after all these restrictions. As per Global Slavery Index, (2014) Pakistan was ranked on 3rd number among 167 countries and bonded labor became a debatable issue in country while China and India were on first and second rank respectively. Almost, (2058200) human beings were involved in this bonded child labor in Pakistan that was stated as modern way 
of slavery. It was also calculated that if we combined bonded laborer of the three countries including India, Thailand and Pakistan, it was almost equal to half of total estimated bonded labor of the world (Ali, 1999).

Bonded laborers were those individuals who took loan and afterwards, they were forced for long working hours and all the days in a week. Afterwards, the owner asked them to pay the loan back and in case of failure their families were also forced to work. This cycle of debt moved from one generation to another generation. That debt never got paid and laborer was pressurized so they never get from this slavery (Iqbal, 2006).

Like other South Asian countries, Pakistan is also marked for debt bondage which remained an ugly part of carpet weaving industry, agriculture, brick kilns, fisheries, shoemaking, workshops, stone crushing, scavenging and refuses to sort. Statistics show that eight million child laborers are working in different sectors of Pakistan, though the given figure is very old and outdated and surely new figure will be very high then this one as no satisfactory progress has been shown regarding the eradication of child labor or debt bondage. The occurrence of bonded labor or debt bondage in brick kilns is so common in all the four provinces of Pakistan. Among which majority is found in brick kilns that are in the province of Punjab (Ercelawn \& Karamat, 2002).

In the latest report issued in 2013, Pakistan has been declared among the top position holder countries "Slavery's List of Shame". And among the total 185.13 million people in 2014, the Global Slavery Index Reported that more than one percent people are enslaved in Pakistan. A campaign has been done for the enrollment of those children who work in brick kiln in nearby schools, by Punjab government on August 26, 2015. The main agenda of the campaign was the enrollment of students aged 14 years old in different schools that were near to brick kilns. The deadline to fulfill this task was the end of October 2015.

\section{Literature Review}

\section{Socio-Economic Aspects of Child Labor}

Several factors are contributing in the raise of child labor in developing nations. Many researchers investigated and stated that poverty is the main accountable feature for bonded child labor. The social scientist and researchers have focused on several dimensions of child labor. The primary and secondary data both were considered for analysis. All study's findings indicated that poverty, large family units, single parenthood are the main root factors which are playing a detrimental role in the increasing of child labor in different formal and informal working settings which automatically lead towards exploitations. Nevertheless, there are other social and cultural forces which influence the rise of child labor in developing countries including Pakistan (Irfan \& Hamid, 1981; Khan, 1982; Ali \& Hamid, 1999; and Basu \& Kaushik, 1999). 
Bhalotra (2007) has examined the association between poverty and child labor. She had used a large household survey from rural Pakistan and estimated labor supply models for boys and girls in wage work. She had found that "poverty is associated with the supply of child labor into the active workforce".

Behera (2007) associated the problem of child labor with poverty, insufficient educational system, and employment. She argued that child labor is the highly noticeable problem in the 21st Century in South Asia. Many of the children are working in various fields and pooling their families' economy. They are working in high miserable conditions and exploited by their work owner. She also pointed out that child labor is both the cause and consequence of poverty. However, she acknowledges the role of society and cultural discourse in the increase of child labor and it is in the shape of traditional practices and gender disparity.

\section{Material and Methods}

The research study was conducted under quantitative methodology through using the simple random sampling in Peshawar. ILO report (2012) highlighted that there were 500 brick kilns craftsmanship, only 380 were practical and the 60 brick kilns were chosen as a sample. From sixty brick kilns two children, two parents and one owner from each kiln were chosen by using the simple random sampling. In this way the researcher selected 120 parents, 120 children and 60 owners of brick kilns through table of sample size Sekaran (2003). The researcher used the interview schedule as a tool for data gathering from respondents. Interview schedule was used because majority of the respondents were illiterate or felt hesitation to fill the questionnaire. The data was analyzed by using the Statistical Package for Social Science (SPSS) and hypothesis were tested by using the Chi-square.

\section{Hypothesis}

Higher the debt bondage, greater would be exploitation of parents' and children's services by brick kilns owners

\section{Results and Discussion}

Table No 01

Chi-Square Tests Showing association between financial problem and Bonded Child Labor

\begin{tabular}{|c|c|c|c|c|c|}
\hline & Value & Df & $\begin{array}{l}\text { Asymp. Sig. } \\
\text { (2-sided) }\end{array}$ & $\begin{array}{l}\text { Exact Sig. (2- } \\
\text { sided) }\end{array}$ & $\begin{array}{l}\text { Exact Sig. (1- } \\
\text { sided) }\end{array}$ \\
\hline Pearson Chi-Square & $2.118^{a}$ & 1 & .146 & & \\
\hline $\begin{array}{l}\text { Continuity } \\
\text { Correction }^{\mathrm{b}}\end{array}$ & .941 & 1 & .332 & & \\
\hline Likelihood Ratio & 3.586 & 1 & .058 & & \\
\hline Fisher's Exact Test & & & & .333 & .169 \\
\hline
\end{tabular}




\begin{tabular}{cccc}
$\begin{array}{c}\text { Linear-by-Linear } \\
\text { Association }\end{array}$ & 2.082 & 1 & .149 \\
\hline $\mathrm{N}$ of Valid Cases & 60 & & \\
\hline
\end{tabular}

Table number 01showed a non-significant $(\mathrm{p}=0.169)$ link between the financial problems facing by children and the bonded labor.It showed that majority of the respondents were answered that the children who worked at brick kilns were not faced financial problems. They claimed that the bounded children did not face fiscal issues. The findings of the study conducted by Behera (2007) were different from the results of present study. Behera found that poverty and unemployment were the causes of child labor and further argued that child labor was the greatly noticeable issue in the $21^{\text {st }}$ Century in South Asia. The countless children were working in different fields and sharing their families' budget. They were exploited and faced miserable conditions during their work. It was further argued that child labor was the main cause of poverty.

Table No 02

Chi-Square Tests Showing association between Total Advance Money and Bonded Child Labor

\begin{tabular}{cccc}
\hline & Value & Df & Asymp. Sig. (2-sidec \\
\hline Pearson Chi-Square & $52.549 \mathrm{a}$ & 5 & .000 \\
\hline Likelihood Ratio & 42.784 & 5 & .000 \\
\hline Linear-by-Linear Association & 14.845 & 1 & .000 \\
\hline N of Valid Cases & 60 & & \\
\hline
\end{tabular}

Table number 02 showed no significant $(p=0.000)$ difference between the children takes the advance money and the bonded child labor. Majority of the respondents answered that bonded child labor took advance money from the owner of brick kilns. If the workers of brick kilns needed advance money and could not timely return to them than it will lead them towards bonded child labor. In this way the owners of brick kilns found a reason of their exploitation and compel them to work for long hours and gave low wages as well. Rogaly (2008) highlighted that the findings of current study was also endorsed by the Report of National Coalition Against Bonded Labor, "The State of Bonded Labor in Pakistan. "Bonded labor denotes to work, which is completed by any individual of the bonded family for their owner on insignificant wages on weekly fee; until the loan is repaid. In the agreement period of "Peshgi" (advance payment) the debt-bonded family did not seek engagement or any income generation basis and move freely outdoor". After examining the primary data, the findings proved the hypothesis.

Table No 03

Chi-Square Tests Showing association between Loan Burdon and Bonded Child Labor

\begin{tabular}{cccccc}
\hline & Value & Df & $\begin{array}{c}\text { Asymp. Sig. Exact Sig. (2. } \\
\text { (2-sided) }\end{array}$ & $\begin{array}{c}\text { Exact Sig. (1- } \\
\text { sided })\end{array}$ & sided $)$ \\
\hline Pearson Chi-Square & $13.958^{\mathrm{a}}$ & 1 & .000 & & \\
\hline
\end{tabular}




\begin{tabular}{cccccc}
\hline Continuity Correction $^{\mathrm{b}}$ & 9.818 & 1 & .002 & & \\
\hline Likelihood Ratio $^{\text {Fisher's Exact Test }}$ & 9.769 & 1 & .002 & & .003 \\
\hline $\begin{array}{c}\text { Linear-by-Linear } \\
\text { Association }\end{array}$ & 13.725 & 1 & .000 & & .003 \\
\hline N of Valid Cases & 60 & & & & \\
\hline \hline
\end{tabular}

Table number 3 showed no $(\mathrm{p}=0.003)$ difference between loan burden and bonded child labor. It showed that majority of the respondents believed that owner of the industries did not give enough cash on proper time to bonded child labor and that led them towards borrowing from the owners of brick kilns for fulfilling their daily routine necessities. The owners of the brick kilns trap them in the deprived circle of poverty. Afzal (2006) also certified that the bricks kilns industry, "peshgi" mechanism was frequent used and the workers and owners of brick kilns have accepted on it as a custom. Debt bondage was in the custom of "peshgi" and was a century-old exercise in Pakistan. It defined an oral contract which was usual on the periodic calendar of brick kilns. Laborers got "peshgi" through "Jamadar" in Punjab that individual also called work Mate that was answerable for entering into an contract (verbal) of "peshgi" between laborers and owner. Such exercise has several requirements on the owners and the working class as well. Every individual of the bondage household was trying to decrease the burden of obligation but inopportunely due to certain socio-cultural conditions the laborers were highly distress. The load of debt was so long-lasting that individuals could not get free from debt.

\section{Conclusion and Recommendations}

It could be concluded that the bonded laborer face a lot of difficulties in daily routine of life. They did not fulfill the elementary needs of their life. For the gratification of their prerequisites, they compelled to work as a bonded labor and majority of them were the kids. Poverty and joblessness were the main reasons of the bonded child labor. The financial issues were the main reason of bounded child labor. The owners of the brick kiln economically facilitate the workers and started to exploited them in the shape of bounded them to work with their children and in this way the deprivation cycle became start for the working class and they became compelled to do bounded labor. This cycle became the source of socially exclusion. It is suggested that government of Pakistan should have to ensure to implement on the constitution of Pakistan 1973, 26 (A) "Every child 5-16 years old get free and compulsory education without discrimination". Government of Pakistan should have to root out the responsible people who violate the national and international commitments against the violation of children rights. 


\section{References}

Afzal, A. (2006). Pakistan, the WTO, and Labor Reform. BC Int'l \& Comp. L. Rev., 29, 107.

Ali, K., \& Hamid, A. (1999). Major determinants of female child labour in urban Multan (Punjab-Pakistan), The Lahore Journal of Economics, Vol.4, No.1, 61-78.

Ali, M. Z. (1999). Development of Working Children and their Households in Liyari and Orangi Areas of Karachi: Need Assessment Study for Skill Development. Pakistan Institute of Labour Education and Research: Karachi.

Basu, K. (1999). Child Labour: Causes, Consequences and Cure, with Remarks on International Labour Standards, Journal of Economic Literature, India 37(3). P. 7.

Basu, K., and Van, P.H. (1998). The Economics of Child Labor. American Economic Review 88:3.412-27.

Behera, D. K. (2007). Childhood in South Asia. Pearson: New Delhi.

Bhalotra, S. (2007). Is Child Work Necessary? Oxford Bulletin of Economics and Statistics, Vol. 69, No. 1. Pp. 12-17.

Chaudhry, A., \& Garner, P. (2007). Do governments suppress growth? Institutions, rent-seeking, and innovation blocking in a model of Schumpeterian growth. Economics \& Politics, 19(1), 35-52.

Emerson, P.M., and André, P.S. (2003). Is There a Child Labor Trap? InterGenerational Persistence of Child Labor in Brazil.Economic Development and Cultural Change 51:2.375-98.

Ercelawn, A., \&Karamat, A. (2002). Bonded Labor in Pakistan: Impacts of Policy, Law and Economy. The Journal, 7(1), 23-29.

Hugh, D.H. (2009). The World of Child Labor: An Historical and Regional Survey, M.E.Sharpe Armonk, New York-London, England.

Human Rights Commission of Pakistan. (2012). Consultation Workshop on Bonded Labour, Press Release by HRCP, June 25, 2012: Lahore Pakistan.

ILO Global Report. (2006). The end of Child Labor: Within reach, International Labour Organization, Geneva.

International Labour Organization (ILO). (2004). Child labour: Text Book, Geneva.

Iqbal, M.J. (2006). Bonded Labour in Bricks Kilns in Punjab. Lahore: Journal of Economics, vol. 11, issue 1, 99-119. 
Irfan and Hamid. (1981). Child Labour in Pakistan. The Pakistan Development Review 1994. P. 1249.

Khan and Shaheen. (1982). Labour Force Participation of Children. The Pakistan Development Review 1994. p. 1250.

Rogaly, B. (2008). Migrant workers in the ILO's Global Alliance Against Forced Labour report: A critical appraisal. Third World Quarterly, 29(7), 1431-1447.

Sekaran, U. (2003). Research Methods for Business. USA, Hermitage Publishing Services.

Shaheen. (1982). Compelled Child Labour in Punjab: A Case Study. Lahore, Punjab Economic Research Institute. pp. 72-77. 